\title{
MISMATCH TRACER STUDY DAN DESAIN SILABUS
}

\author{
Edy Subali
}

\begin{abstract}
Mismatch dipicu oleh kurang adanya komunikasi antara dunia industri, pasar kerja dengan dunia pendidikan. Dunia pendidikan belum responsif atau cenderung terlambat menyikapi perkembangan industri dan dinamika pasar kerja. Upaya penyelesaian problem penyelarasan antara keduanya selama ini masih bersifat parsial dan sporadis. Kualitas kompetensi pekerja belum memenuhi kebutuhan industri dan pasar kerja; tingkat produktivitas kerja masih rendah; penciptaan usaha baru dan mandiri sebagai wujud kemampuan berwirausaha belum optimal. Mismatch adalah masalah kurang "berjodoh" antara dunia pendidikan dengan dunia industri/dunia kerja. Indikatornya adalah pengangguran. Pengangguran sarjana merupakan fenomena kasat mata yang masih banyak dibicarakan daripada diselesaikan. Dunia pendidikan sebagai penanggung jawab dalam pengelolaannya mendapatkan tantangan serius untuk mengatasinya. Dengan informasi dari tracer study maka rancangan kurikulum dan silabus akan mendapatkan masukan yang tepat dan akurat. Dengan dasar pijakan hasil tracer study tersebut maka paling sedikit dapat menginspirasi pengembangan desain kurikulum dan silabus dalam tiga hal, yaitu: (1) kompetensi apa dan dengan standar minimal seberapa yang diperlukan dunia industri sehingga SDM lulusan dengan kompetensi tersebut dapat memiliki keunggulan komparatif dan kompetitif, bukan saja dalam skala lokal dan nasional tetapi sekaligus dalam skala dunia/global, (2) dengan jelasnya kompetensi yang diperlukan tersebut (apa kompetensi yang dibutuhkan dan seberapa standar minimalnya dari tracer study) maka dapat diketahui pula tentang pendekatan, metode, teknik, dan strategi pembelajaran yang harus dilakukan untuk mengasah dan membentuk kompetensi tersebut, (3) dengan jelasnya kompetensi yang diperlukan tersebut (apa dan seberapa standar minimalnya dari tracer study) maka dapat diketahui pula tentang apa saja yang perlu dievaluasi (kognisi, afeksi dan psikomotorik) dan bagaimana caranya untuk mengevaluasi atau mengukur bahwa standar kompetensi dan kompetensi dasar sudah dimiliki oleh peserta didik.
\end{abstract}

Kata kunci: mismitch, tracer study, kesenjangan, pengangguran sarjana, dunia pendidikan, dunia industri atau dunia kerja.

Pendidikan merupakan suatu kegiatan mulia jika dipahami dari misi substansialnya. Demikian besarnya faedah, manfaat, dan nilai tambah kegiatan pendidikan dalam kehidupan ini. Manusia, dari tidak tahu menjadi tahu, dari tidak bisa menjadi bisa, dari tidak bermoral menjadi bermoral, dari tidak memiliki falsafah hidup menjadi memilikinya adalah karena pendidikan. Pendidikan berurusan langsung dengan proses pembentukan figur dan profil manusia. Figur dan profil manusia seperti apa yang diharapkan terbentuk sangat dipengaruhi oleh pendidikan. Orang tua, bapak dan ibu guru, dosen, pemerintah dan masyarakat sama-sama mempunyai andil dalam proses pembentukan model manusia. Kutipan berikut ini memperjelas gambaran tentang visi dan misi pendidikan nasional. 
Pendidikan adalah usaha sadar dan terencana untuk mewujudkan suasana belajar dan proses pembelajaran agar peserta didik secara aktif mengembangkan potensi dirinya untuk memiliki kekuatan spiritual keagamaan, pengendalian diri, kepribadian, akhlak mulia, serta keterampilan yang diperlukan dirinya, masyarakat, bangsa dan negara (Undang-Undang Republik Indonesia, Nomor 12 Tahun 2012 tentang Pendidikan Tinggi).

Visi pendidikan nasional adalah terwujudnya sistem pendidikan sebagai pranata sosial yang kuat dan berwibawa untuk memberdayakan semua warga negara Indonesia berkembang menjadi manusia yang berkualitas sehingga mampu dan proaktif menjawab tantangan zaman yang selalu berubah (Lampiran Permendiknas 41 Tahun 2007 tentang Standar Proses Pendidikan Dasar dan Menengah).

Misi pendidikan nasional adalah: (a) mengupayakan perluasan dan pemerataan memperoleh pendidikan yang bermutu bagi seluruh rakyat Indonesia, (b) meningkatkan mutu pendidikan yang memiliki daya saing di tingkat nasional, regional, dan internasinal, (c) meningkatkan relevansi pendidikan dengan kebutuhan masyarakat dan tantangan global, (d) membantu dan memfasilitasi pengembangan potensi anak bangsa secara utuh sejak usia dini sampai akhir hayat dalam rangka mewujudkan masyarakat belajar, (e) meningkatkan kesiapan masukan dan kualitas proses pendidikan untuk mengoptimalkan pembentukan kepribadian yang bermoral, (f) meningkatkan keprofesionalan dan akuntabilitas lembaga pendidikan sebagai pusat pembudayaan ilmu pengetahuan, keterampilan, pengalaman, sikap dan nilai berdasarkan standar yang bersifat nasional dan global, (g) mendorong peran serta masyarakat dalam penyelenggaraan pendidikan berdasarkan prinsip otonomi dalam konteks Negara Kesatuan Republik Indonesia (Penjelasan Permendiknas Nomor 19 Tahun 2005 tentang Standar Nasional Pendidikan).

Hampir semua orang dikenai pendidikan dan melaksanakan pendidikan. Pendidikan tidak pernah terpisah dari kehidupan manusia. Awalnya, pendidikan bersifat insting atau naluri, misalnya: rasa melindungi anak, rasa cinta terhadap anak, bayi menangis, kemampuan menyusu air susu ibu dan merasakan kehangatan dekapan ibunya. Mendidik secara insting kemudian diikuti oleh mendidik yang 
bersumber dari pikiran dan pengalaman manusia. Manusia mampu menciptakan caca-cara mendidik karena perkembangan pikiran dan pengalamannya.

Pekerjaan mendidik mencakup segala hal yang berkaitan dengan perkembangan manusia, mulai dari perkembangan fisik, mental, pikiran, kemauan, sosial, ekonomi, keterampilan sampai pada perkembangan iman. Mendidik bermaksud membuat manusia menjadi lebih sempurna, membuat manusia meningkatkan hidupnya dari kehidupan alamiah menjadi berbudaya. Mendidik adalah membudayakan manusia (Made Pidarta, 1997:1-2). Membudayakan manusia berarti membuat mereka memiliki kapasitas dan kapabilitas pengetahuan, sikap dan tindakan atauperbuatan baik dan benar sehingga tergolong beradab. Hal ini sejalan dengan tujuan pendidikan nasional, yaitu meningkatkan kualitas manusia, yaitu manusia yang beriman dan bertakwa terhadap Tuhan Yang Maha Esa, berbudi pekerti luhur, berkepribadian, mandiri, maju, tangguh, cerdas, kreatif, terampil, berdisiplin, beretos kerja, profesional, bertanggung jawab, dan produktif serta sehat jasmani dan rohani;menumbuhkan jiwa patriotik dan mempertebal rasa cinta tanah air, meningkatkan semangat kebangsaan dan kesetiakawanan sosial serta kesadaran pada sejarah bangsa dan sikap menghargai jasa pahlawan, serta berorientasi masa depan (Oemar Hamalik, 2003:5).

Berdasarkan uraian di atas dapatlah direnungkan dan diamati, apakah harapan sebagaimana tergambar dengan jelas dalam (1) UU RI No. 20 Tahun 2003 tentangSistem Pendidikan Nasional, (2) Peraturan Pemerintah Nomor 19 Tahun 2005 tentang Standar Nasional Pendidikan sudah benar-benar menjadi kenyataan? Singkatnya, apakah harapan sebagaimana tertuang dalam visi dan misi pendidikan nasional tersebut sudah dapat direalisasikan sehingga menjadi kenyataan? Menjawab dengan tepat dan benar terhadap pertanyaan tersebut tentu perlu penelitian. Yang penting, upaya menemukan gap atau kesenjangan antara harapan dan kenyataan adalah sesuatu yang sangat diperlukan agar persoalan-persoalan terkait dengan pendidikan dan pembelajaran dapat diidentifikasi dan dideskripsikan dan pada gilirannya diupayakan dicari alternatif pemecahannya.

Mutu pendidikan di Indonesia sering dikeluhkan oleh banyak kalangan. Berarti, apa yang diharapkan belum sepenuhnya bisa direalisasi menjadi kenyataan. 
Dalam Bahan Uji Publik Kurikulum 2013 (29 November 2012) secara eksplisit dipaparkan tentang kebutuhan yang perlu diantisipasi oleh kurikulum dan desain silabus pendidikan.

\begin{tabular}{|c|c|}
\hline TANTANGAN MASA DEPAN & KOMPETENSI MASA DEPAN \\
\hline $\begin{array}{r}\text { - Globalisasi: WTO, ASEAN } \\
\text { Community, APEC, CAFTA }\end{array}$ & - Kemampuan berkomunikasi \\
\hline - Masalah lingkungan hidup & $\begin{array}{l}\text { - Kemampuan berpikir jernih dan } \\
\text { kritis }\end{array}$ \\
\hline - Kemajuan teknologi informasi & $\begin{array}{c}\text { - Kemampuan mempertimbangkan } \\
\text { segi moral suatu permasalahan }\end{array}$ \\
\hline - Konvergensi ilmu dan teknologi & $\begin{array}{l}\text { - Kemampuan menjadi warga negara } \\
\text { yang bertanggung jawab }\end{array}$ \\
\hline - Ekonomi berbasis pengetahuan & $\begin{array}{l}\text { - Kemampuan mencoba untuk } \\
\text { mengerti dan toleran terhadap } \\
\text { pandangan yang berbeda }\end{array}$ \\
\hline $\begin{array}{l}\text { - Kebangkitan industri kreatif dan } \\
\text { budaya }\end{array}$ & $\begin{array}{l}\text { - Kemampuan hidup dalam } \\
\text { masyarakat yang mengglobal }\end{array}$ \\
\hline $\begin{array}{l}\text { - Pergeseran kekuatan ekonomi } \\
\text { dunia }\end{array}$ & $\begin{array}{l}\text { - Memiliki minat luas dalam } \\
\text { kehidupan }\end{array}$ \\
\hline - Pengaruh dan imbas teknosains & - Memiliki kesiapan untuk bekerja \\
\hline $\begin{array}{l}\text { - Mutu, investasi dan transformasi } \\
\text { pada sektor pendidikan }\end{array}$ & $\begin{array}{l}\text { - Memiliki kecerdasan sesuai } \\
\text { dengan bakat/minatnya }\end{array}$ \\
\hline • Hasil TIMSS dan PISA & $\begin{array}{l}\text { - Memiliki rasa tanggung jawab } \\
\text { terhadap lingkungan }\end{array}$ \\
\hline $\begin{array}{l}\text { FENOMENA NEGATIF } \\
\text { YANG MENGEMUKA }\end{array}$ & PERSEPSI MASYARAKAT \\
\hline - Perkelahian pelajar & $\begin{array}{l}\text { - Terlalu menitikberatkan pada } \\
\text { aspek kognisi }\end{array}$ \\
\hline - Narkoba & - Beban siswa terlalu berat \\
\hline - Korupsi & - Kurang bermuatan karakter \\
\hline - Plagiarisme & \\
\hline $\begin{array}{l}\text { - Kecurangan dalam ujian (contek, } \\
\text { kerpek) }\end{array}$ & \\
\hline - Gejolak masyarakat (social unrest) & \\
\hline
\end{tabular}

Permasalahan ironis dan perlu segera dikaji untuk dicari solusinya adalah kecenderungan semakin meningkatnya pengangguran sarjana. Opini bahwa perguruan tinggi adalah "institusi pendidikan tinggi pencetak pengangguran," terasa semakin terbentuk. Indikasi kuat akan adanya mismatch? 
Masalah mismatch adalah masalah tidak/kurang "bertemu", kurang "berjodoh", kurang "setel" antara dunia kerja dan dunia pendidikan. Lonjakan jumlah sarjana menganggur tidak semakin menurun. Jumlah pengangguran tingkat sarjana di Indonesia terus meningkat dari tahun ke tahun. Pada tahun 2007, jumlahnya sekitar 740.000, dan awal tahun 2009 bertambah mendekati angka satu juta atau lebih dari 900.000 sarjana yang menganggur. Hal itu disampaikan Rektor Universitas Katolik Atma Jaya, FG Winarno, saat pengukuhan guru besar fakultas teknik Unika Atma Jaya, Prof. Hadi Sutanto, di Jakarta, Rabu (17/6). Prof. Winarno mengaku prihatin dengan kondisi sarjana yang menganggur saat ini, yang menurutnya memiliki tren kenaikan rata-rata sebesar 20 persen setiap tahun (Suara Pembaruan, 17 Juni 2009).

Berdasarkan informasi yang diperoleh Suara Pembaharuan, pada 2005 sarjana yang menganggur sebanyak 183.629 orang. Setahun kemudian, yakni 2006 tercatat 409.890 lulusan tidak memiliki pekerjaan, tahun 2007 menjadi 740.000, dan awal tahun 2009 melonjak mendekati angka satu juta sarjana pengangguran. Hal ini harus diwaspadai, mengingat setiap tahunnya Indonesia menghasilkan sekitar 300.000 sarjana dari 2.900 perguruan tinggi. Menurut beliau, makin banyaknya sarjana yang menganggur disebabkan oleh rendahnya soft skill atau keterampilan di luar kemampuan utama dari sarjana yang bersangkutan.

Data-data tersebut menunjukkan bahwa masalah mismatch sebagai masalah serius. Mismatch antara dunia pendidikan dengan dunia kerja memang wajar terjadi karena dunia kerja cenderung bergerak atau berkembang lebih cepat dari dunia pendidikan. Akan tetapi tidaklah arif dan bijasana apabila dunia pendidikan tidak diupayakan "berjodoh" bahkan menjadi "abdi" dunia kerja. Dengan pesan yang serupa, Dirjen Dikti dalam kata pengantar Buku Panduan Sistem Pusat Kariredisi II menulis seperti:

“...pendidikan tinggi sebagai penghasil tenaga kerja terdidik ternyata berjarak dengan dunia kerja dan kenyataan di lapangan menunjukkan a.l. (1) masih tingginya jumlah penganggur terbuka, (2) kualitas kompetensi pekerja belum memenuhi kebutuhan pasar kerja dan tingkat produktivitas kerja masih rendah, (3) kesenjangan upah antar pekerja masih relatif besar, (4) kesenjangan gender, (5) kesulitan daerah tertinggal untuk mendapatkan tenaga kerja yang profesional, di sisi lain masih tinggi pengangguran di wilayah lain, (6) rendahnya penciptaan usaha baru dan kemampuan berwirausaha, (7) belum 
optimalnya informaasi pasar kerja yang dinamis dan terkini, (8) kurang adanya komunikasi antara pasar kerja dengan dunia pendidikan, (9) internal dunia pendidikan (sarana dan prasarana, fasilitator, sistem pembelajaran) belum responsif atau selalu terlambat menyikapi perubahan pasar kerja, (10) upaya penyelesaian problem penyelarasan selama ini masih bersifat parsial dan sporadis, (11) belum siapnya mesyarakat industri maupun tenaga kerja dalam menghadapi Asia China Free Trade Agreement (ACFTA)."

Persoalannya, dalam upaya penyelarasan tersebut, dunia pendidikan, terutama pihak pembuat kebijakan pendidikan, pengembang desain instruksional, pengembang kurikulum dan silabus, apakah sudah secara optimal memanfaatkan konsep market signal, identifications of needs atau needs analysis, dan tracer study? Identifikasi dan analisis kebutuhan akan menjadi terbantu apabila pelaksanaan tracer study oleh satuan pendidikan dapat berjalan dengan optimal. Dalam kata pengantar Buku Panduan sistem Pusat Karir edisi II, Dirjen Dikti menyatakan:

"Pendidikan yang selaras dengan kebutuhan dunia usaha dan industri akan menjamin kualitas yang berkelanjutan. Sebagai salah satu indikator penting dalam kualitas pendidikkan, relevansi menjadi kata kunci yang harus diperhatikan dalam membangun dan mengembangkan pendidikan tinggi di Indonesia. Untuk menunjang perkembangan ilmu, pengetahuan, teknologi dan ekonomi, pendidikan tinggi perlu mempertimbangkan aspek keselarasan kebutuhan tenaga SDM dengan program studi yang ditawarkan.”

Pernyataan tersebut menandakan bahwa tracer study (TS) sangat penting dipahami dan dilakukan oleh setiap perguruan tinggi. TS merupakan salah satu upaya penyelarasan antara dunia pendidikan dengan dunia kerja, industri dan kondisi global. Dengan TS maka mudah diketahui tentang penyerapan, proses dan posisi lulusan PT dalam dunia kerja. Akibat lanjutannya, menyiapkan lulusan sesuai dengan kompetensi yang diperlukan dunia kerja. Berarti sajian menu dalam kurikulum, silabus, RPP dan metode, serta materi dan fasilitas dalam proses pembelajaran di kelas akan menyesuaikannya.

\section{Permasalahan}

a) Bagaimana kurikulum dan desain silabus pendidikan memiliki relevansi dengan kebutuhan industri dan perubahan jamanhanya dengan tracer study? 
b) Bagaimana pemerolehan kompetensi pendidikan dapat sesuai dengan kebutuhan/persyaratan lapangan kerja hanya dengan tracer study?

\section{Tujuan dan Manfaat}

a) Paparan/tulisan ini bertujuan untuk memperoleh kesimpulan rasionalobyektif bahwa dengantracer studydapat diketahui daya serap, proses dan posisi lulusan dalam dunia industri/dunia kerja.

b) Untuk memperoleh kesimpulan rasional-obyektif bahwa tracer study dapat menjembatani keperluan dunia industri/dunia kerja dengan dunia pendidikan, terutama dalam hal pengembangan kurikulum dan desain silabus atau rencana kompetensi dasar yang harus dicapai pembelajar. Dengan demikian bermanfaat dalam menyiapkan lulusan sesuai dengan kompetensi yang diperlukan dunia industri/dunia kerja.

c) Untuk memperoleh kesimpulan rasional-obyektif bahwa dengan tracer study dapat membantu program pemerintah dalam rangka memetakan dan menyelaraskan kebutuhan dunia industri/dunia kerja dengan pendidikan tinggi di Indonesia.

Dunia pendidikan, dunia kerja, dunia industri dan perubahan jaman berbeda, tetapi antara ketiganya tidak bisa dipisahkan. Perubahan jaman yang sudah masuk dan berada dalam situasi dan kondisi global ini menjadi faktor vital yang harus menginspirasi dunia pendidikan. Standar kompetensi dan kompetensi dasar dirumuskan sejalan dengan tuntutan globalisasi. Dengan demikian, silabus sebagai jabaran dan rancangan pencapaian standar kompetensi dan kompetensi dasar perlu penyesuaian atau penyelarasan dengan tuntutan globalisasi. Prinsip pengembang-an silabus, seperti relevan, aktual, kontekstual, ilmiah, sistematis, dan fleksibel menjadi kata kuncinya.

Konsep link and match antara dunia pendidikan dan dunia kerja atau industri pernah dicanangkan oleh mantan Mendiknas Prof. Dr. Wardiman Djojonegoro pada tahun 1990-an. Pro dan kontra terhadap konsep tersebut tampak menggejala di masyarakat, bahkan sampai saat ini. Soemarso, Ketua Dewan Pembina Politeknik dan juga dosen UI mengatakan bahwa konsep link and match antara dunia 
pendidikan dan dunia kerja dianggap ideal. Ada keterkaitan antara pemasok tenaga kerja dan penggunanya. Ia menilai, dengan adanya hubungan timbal-balik membuat PT (Perguruan Tinggi) dapat menyusun kurikulum sesuai dengan kebutuhan kerja.

Tingginya tingkat pengangguran di republik ini sepertinya sudah pada tahap “lampu kuning.” Bayangkan saja, dari 230 juta jiwa penduduk Indonesia, 119,4 juta jiwa merupakan angkatan kerja, sebagiannya merupakan pengangguran. Dari pengangguran tersebut didominasi oleh lulusan sarjana. "Penyebabnya karena belum ada link and match antara supply dan demand di dunia kerja. Ini yang menyebabkan banyaknya pengangguran tingkat sarjana," kata Deputi Menteri Bidang Pengembangan SDM Kementerian Koperasi dan UKM Agus Muharam, saat acara pembukaan Program Magang Nasional 2011 di Jakarta (Selasa, 1 Januari 2011).

Menurut Hendra Suryono (dalam Noor Fitrihana) pada era globalisasi dan tingginya velositas menuntut pengelolaan sumber daya yang ada dengan tepat, terutama sumber daya yang terbarukan (renewable), yaitu keterampilan dan keahlian tenaga kerja agar tetap selaras dengan kemajuan teknologi yang sangat cepat dan perubahan pasar. Hal ini menuntut departemen SDM di perusahaan untuk mampu mengelola SDM di perusahaan dengan baik sehingga kontinuitas dan ketepatan produksi terjamin. Output lembaga pendidikan yang sesuai dengan kebutuhan industri hanya akan terwujud jika pelaksanaan pendidikan dipacu oleh industri dan industri hanya akan eksis jika didukung ketersediaan SDM yang berkualitas dari lembaga pendidikan. Tujuan pendidikan dan kebutuhan industri yang saling terkait ini perlu diikat lebih erat dengan membangun pola kemitraan antara lembaga pendidikan dan industri.

Selain ada yang pro link and match, ada juga yang kontra. Menyiapkan lulusan PT siap bekerja adalah nonsen dan tak mungkin terjadi. Kesannya, bekerja adalah kegiatan amat teknis dan praktis saja. Padahal bekerja ada beberapa level, mulai dari sangat teknis (mengetik, mengarsip) hingga level strategis bagaimana membangun pasar, menciptakan image bahwa produk yang dihasilkan adalah sangat dibutuhkan mmasyarakat (www.kabar.pendidikan.blogspot.com,www.kmp-malang.com). 
Direktur Consulting People Performance Consulting, Riri Satria mengatakan bahwa suatu hal yang tidak mungkin bila lulusan PT siap $100 \%$ kerja sesuai dengan kebutuhan perusahaan. Setiap perusahaan itu unik dan tidak ada yang persis sama, mulai dari aspek strategi bisnisnya, struktur organisasinya, sistem dan prosedur kerjanya, budaya organisasinya, bahkan sistem nilai perusahaannya. Buat Riri, yang ideal sebuah PT mampu memberikan kompetensi yang sifatnya umum, mulai dari aspek teori sampai teknis (termasuk praktek menggunakannya), sedangkan perusahaan berkewajiban memberikan pelatihan kepada lulusan tersebut terkait kekhasan kerusahaannya. Riri juga berpendapat bahwa perusahaan memang harus melakukan investasi pada SDM untuk mendapatkan SDM yang unggul, yaitu dengan memadukan kompetensi yang generik di bidangnya dengan kompetensi yang spesifik dibutuhkan perusahaan. Ia menilai, pada zaman ini, salah besar kalau ada perusahaan yang masih menganggap pengembangan SDM sebagai beban karena sesungguhnya itu juga sebuah investasi. Inilah esensi sesunggunya dari konsep human capital.

Kesulitan membawa pihak industri dan bisnis terlibat dengan sepenuh hati ke dunia pendidikan dapat dimaklumi karena belum adanya cetak biru kerja sama yang saling menguntungkan kedua belah pihak serta belum adanya aturan atau undangundang yang dapat mengikat kedua pihak sehingga konsep link and match yang digagas lebih dari dua dekade lalu tidak dapat dilaksanakan teratur dan sistemik. Jangankan untuk PT, sekolah vokasi atau kejuruan dan politeknik yang para lulusannya memang disiapkan untuk bekerja masih belum efektif bekerja sama dengan dunia industri.

Berdasarkan beberapa pandangan tentang konsep link and match antara dunia pendidikan dengan dunia industri, paling sedikit ada tiga persoalan serius yang perlu segera diatasi oleh pengelola dan pelaksana pendidikan di Indonesia. Pertama, masalah pengangguran, kedua masalah pendidikan (kurikulum, desain silabus dan proses pembelajarannya), dan ketiga masalah perubahan jaman yang bergerak cepat menuju globalisasi. Ketiga persoalan ini saling pengaruh mempengaruhi. Pengangguran harus diakui dan disadari terjadi sebagai akibat dunia pendidikan kurang memenuhi standar yang diharapkan dunia industri, pasar keja dan kehidupan 
kompleks masa depan, misalnya globalisasi. Sedangkan pendidikan dan proses pembelajaran sebagai kegiatan kompleks perlu terus dibenahi dan disempurnakan agar selalu match atau berjodoh dan setel dengan perubahan dan globalisasi.

Globalisasi memang sudah menginspirasi elit pembuat kebijakan pendidikan kita untuk melakukan pengembangan instruksionalnya, memperbarui paradigma pembelajaran, yang berakibat juga pada perubahan kurikulum, silabus, rencana pelaksanaan pembelajaran (RPP), termasuk juga pendekatan dan metode pembelajarannya. Perubahan kurikulum nasional 1994 yang berbasiskan isi dan struktur keilmuan menjadi kurikulum yang berbasis pada kompetensi (KBK) pada tahun 2004 dan KTSP tahun 2006 merupakan bukti upaya untuk menyelaraskan (membuat match) kesenjangan antara dunia pendidikan dengan dunia kerja atau dunia industri serta dengan perubahan kondisi global.

Bagaimana dapat membuat kesimpulan yang rasional bahwa dengan tracer study dapat membuatkurikulum dan desain silabus pendidikan relevan dengan kebutuhan indutri dan prubahan? Atas dasar data atau konsep atau pemikiran apa sehingga dapat membuat kesimpulan tersebut?

\section{Pembahasan}

Tracer study adalah studi penelusuran atau pelacakan terhadap posisi lulusan (antara 1-3 tahun) lembaga penyelenggara pendidikan tinggi. Melakukan tracer studybertujuan memperoleh informasi akurat tentang daya serap, proses, profil, posisi dan kompetensi lulusan yang dibutuhkan industri atau dunia kerja. Dengan dasar pijakan hasil tracer study maka paling sedikit dapat menginspirasi pengembangan kurikulum dan desain silabus dalam tiga hal, yaitu: (1) kompetensi apa dan dengan standar minimal seberapa yang diperlukan dunia industri sehingga SDM lulusan dengan kompetensi tersebut dapat memiliki keunggulan komparatif dan kompetitif, bukan saja dalam skala lokal dan nasional tapi sekaligus dalam skala dunia/global, (2) dengan jelasnya kompetensi yang diperlukan tersebut (apa kompetensi yang dibutuhkan dan seberapa standar minimalnya dari tracer study) maka dapat diketahui pula tentang pendekatan, metode, teknik, dan strategi pembelajaran yang harus dilakukan untuk menanamkan/membentuk kompetensi 
tersebut, (3) dengan jelasnya kompetensi yang diperlukan tersebut (apa dan seberapa standar minimalnya dari tracer study) maka dapat diketahui pula tentang apa saja yang perlu dievaluasi (kognisi, afeksi dan psikomotorik) dan bagaimana caranya untuk mengevaluasi atau mengukur bahwa standar kompetensi dan kompetensi dasar sudah dimiliki oleh peserta didik.

Di tengah tumbuh suburnya pendirian pendidikan tinggi baru (sekitar 3000 PTN/PTS) tampak mulai ada perhatian untuk mensinergikan antara visi, misi dan tujuan pendidikan tinggi dengan perubahan-perubahan besar industri dan korporasi di dunia industri/dunia kerja. Kata "mulai ada perhatian" berarti belum tampak ada realisasi seperti yang diharapkan; masih berada pada tahapan awal. KBK, KTSP, tracer study adalah contoh upaya-upaya yang dilakukan dunia pendidikan untuk mensinergikannya dengan dunia industri.

Tracer study memang sudah dijadikan salah satu syarat kelengkapan akreditasi oleh Badan Akreditasi Nasional Perguruan Tinggi (BAN-PT), juga merupakan kelengkapan dalam dokumen Evaluasi Diri yang diperlukan dalam pengajuan proposal melalui Kemendikbud. Kenyataannya, tracer study yang dilakukan perguruan tinggi selama ini masih sangat bervariasi dari segi kualitas. Pemanfaatan informasi yang diperoleh juga belum optimal. Analisis yang dilakukan Fikawati dan Syafiq (dalam Buku Panduan Pusat Karer, 2012:26) diketahui bahwa sampai saat ini informasi dan publikasi mengenai tracer study PT di Indonesi masih sangat sedikit. Selain itu, tracer study di Indonesia sangat bervariasi dari segi kejelasan tujuan, desain dan metodologinya. Jika dibandingkan dengan perkembangan tracer study di negara maju, situasi di Indonesia tertinggal cukup jauh. Di Eropa misalnya, jejaring tracer study bahkan telah menghasilkan penelitian besar yang mencakup negara-negara di Eropa.

\section{Kesimpulan}

Mismatch adalah kenyataan dan permasalahan kasat mata yang tampaknya lebih banyak dibicarakan daripada dicarikan solusinya. Pengelola dunia pendidikan, khsususnya pendidikan tinggi tentu tidak menginginkan opini bahwa "PT sebagai institusi pencetak pengangguran" menjadi kenyataan. Jalan untuk mencari alternatif solusi mismatch sebenarnya sudah ditemukan, yaitu PT wajib melakukan tracer 
study. Hanya keberadaan tracer study di PT pun masih sangat bervariasi, baik dari segi kualitas maupun dari segi kejelasan metodologi dan tujuannya.

Jika kualitas tracer study di PT tidak menjadi perhatian institusi pendidikan, apalagi di level pendidikan tinggi maka kurikulum, desain silabus, Rencana Pelaksanaan Pembelajaran (RPP), materi pembelajaran dan proses pembelajaran-nya cenderung beresiko, yaitu lebih bersifat imajinatif-spekulatif. Akibat lanjutan-nya, eksistensi lulusan PT dipertaruhkan kredibilitas dan kapabilitasnya.

Ada kebijakan pendidikan yang mengarah pada upaya membuat "berjodoh" antara dunia pendidikan dengan dunia industri. Konsep link and mitch, KBK, KTSP, pendidikan vokasional dan tracer study adalah upaya "menjodohkan" antara dunia pendidikan dengan dunia industri atau dunia kerja. Persoalannya antara lain, antara keduanya tampak hanya berada pada posisi "kenal", belum berkembang ke arah merasa saling membutuhkan yang kemudian dipertegas dengan ikatan formal cetak biru kerja sama kemitraan. Tracer study hanyalah sebatas meneliti, mengamati atau mengintip tentang posisi anak didik yang telah lulus PT dalam kehidupan nyata.

\section{Daftar Pustaka}

Friere, Paulo. 2004. Politik Pendidikan, Kebudayaan, Kekuasaan dan Pembebasan. Terjemahan oleh Agung Prihantono dan Fuad Arif Fudiyartanto. Yogyakarta: Pustaka Pelajar.

Hamalik, Oemar. 2003. Kurikulum dan Pembelajaran. Jakarta: Bumi Aksara.

Kementerian Pendidikan dan Kebudayaan Direktorat Jenderal Pendidikan Tinggi Direktorak pembelajaran dan Kemahasiswaan. 2012. Buku Panduan Sistem Pusat Karer Edisi II. Januari 2012.

Kementerian Pendidikan dan Kebudayaan. Bahan Uji Publik Kurikulum 2013. 29 November 2012.

Mohammad Rosyid, Daniel. 2008. Pendidikan Nasional di Era reformasi Mau Kemana? Surabaya: Penerbit SIC.

Mulyasa, E. 2008. Menjadi Guru Profesional menciptakan Pembelajaran Kreatif dan Menyenangkan. Bandung: PT Remaja Rosdakarya

Undang-Undang Republik Indonesia Nomor 12 Tahun 2012 Tentang Pendidikan Tinggi. 
45 - Mismatch : Tracer Study dan Desain Silabus

Undang-Undang Republik Indonesia Nomor 20Tahun 2003 tentang Sistem Pendidikan Nasional.

Peraturan Pemerintah Republik Indonesia Nomor 19 Tahun 2005 Tentang Standar Nasional Pendidikan.

Pidarta, Made. 1997. Landasan Kependidikan Stimulus Ilmu Pendidikan Bercorak Indonesia. Jakarta: PT Rineka Cipta. 